\title{
Physiological Growth Indices of Durum Wheat (Triticum turgidum L. Var. durum) as Affected by Rates of Blended and Nitrogen Fertilizers
}

\author{
Bizuwork Tafes ${ }^{1, *}$, Yibekal Alemayehu ${ }^{2}$ \\ ${ }^{1}$ Ethiopia Institute of Agriculture Research, Debre Zeit Agricultural Research Centre, Debre Zeit, Ethiopia \\ ${ }^{2}$ Collage of Agriculture and Environmental Science, Haramaya University, Haramaya, Ethiopia
}

Email address:

b.tafes@gmail.com (B. Tafes)

${ }^{*}$ Corresponding author

\section{To cite this article:}

Bizuwork Tafes, Yibekal Alemayehu. Physiological Growth Indices of Durum Wheat (Triticum turgidum L. Var. durum) as Affected by Rates of Blended and Nitrogen Fertilizers. American Journal of Life Sciences. Vol. 8, No. 4, 2020, pp. 52-59. doi: 10.11648/j.ajls.20200804.12

Received: July 26, 2020; Accepted: August 5, 2020; Published: August 13, 2020

\begin{abstract}
In order to investigation the effects of blended NPSB and N fertilizer rates on physiological and growth indices in durum wheat, a randomized complete block design in a factorial arrangement and replicated 3 times per treatment was conducted in research field of Debre Zeit Agricultural Research Center in 2017 and 2018 under rain-fed condition. The treatments consisted of 4 levels of blended $\left(0,50,100\right.$, and $\left.150 \mathrm{~kg} \mathrm{NPSB} \mathrm{ha}{ }^{-1}\right)$ and N $(0,46,69$ and $92 \mathrm{~kg}$ $\mathrm{N} \mathrm{ha}^{-1}$ ) fertilizers. The results revealed that leaf area index (LAI) at 64 days after sowing (DAS), crop growth rate (CGR) at 34-64 and 64-94 DAS, relative growth rate (RGR) at 34-64 DAS were significantly $(\mathrm{P}<0.05)$ affected by the interaction effects of blended NPSB and N fertilizers. Chlorophyll content (CHL), plant height $(\mathrm{PH})$, days to heading (DH), and days to physiological maturity (DPM) were significantly influenced only by N levels. The highest LAI (4.50), CGR $\left(4.37 \mathrm{~g} \mathrm{~m}^{-2 \circ} \mathrm{Cdays}^{-1}\right)$ at 34-64 DAS and $\left(14.81 \mathrm{~g} \mathrm{~m}^{-2 \circ} \mathrm{Cdays}^{-1}\right)$ at 64-94 DAS and RGR $\left(0.0077 \mathrm{~g} \mathrm{~g}^{-1 \circ} \mathrm{Cdays}^{-1}\right)$ at 34-64 DAS were observed at combined application of $150 \mathrm{~kg}$ blended NPSB with $92 \mathrm{~kg} \mathrm{~N} \mathrm{ha}^{-1}$. The highest PH $(89.4$ $\mathrm{cm}$ ), CHL (40.09), DH (60.92 days) and DPM (116.75 days) were noted in $92 \mathrm{~kg} \mathrm{~N}$ ha. On overall performance application of $150 \mathrm{~kg}$ NPSB with $92 \mathrm{~kg} \mathrm{~N} /$ ha levels showed better results on the growth and physiological traits of durum wheat as compared to other blended and $\mathrm{N}$ levels.
\end{abstract}

Keywords: Blended, Durum Wheat, Growth Indices

\section{Introduction}

Durum wheat (Triticum turgidum L. var. durum) is a selfpollinated tetraploid cereal and a traditional Mediterranean crop with the Mediterranean Basin being the largest production area worldwide and North Africa the largest import market [1]. In Ethiopia, durum wheat is grown primarily as a rain-fed crop by smallholders in the highlands area. In most of the country, only a single durum wheat crop is grown during the second, longer rainy season (meher) which usually starts in June. In East Shewa Zone, wheat is one of the major cereal crops produced next to tef and maize for the purpose of both home consumption and market. In the zone, out of the total land size of $395,977.48$ hectares planted by cereals, wheat covers $72,164.91$ hectares, which is
$18.2 \%$ of the production area covered by all cereals in $2016 / 17$ cropping season. Durum wheat covers $24 \%$ of the total cultivated lands used for wheat. However, out of the total cereal grain production (952,163.7 tons), wheat accounted for $22.3 \%(212,212.3$ tons $)$, and the average yield of wheat in 2016/17 cropping season was only $2.9 \mathrm{t} \mathrm{ha}^{-1}$ [2]. The average yield is above the national average yield (2.7 tha ${ }^{-}$ $\left.{ }^{1}\right)$ but which is still very low as compared to the yield potential of wheat ( 6 tones $\left.\mathrm{ha}^{-1}\right)$.

The low yield is primarily allied to the depletion of soil fertility due to continuous nutrient uptake of crops, low fertilizer use. In addition, for the last three decades, Ethiopian agriculture depended solely on imported fertilizer products namely urea and di-ammonium phosphate (DAP) which are source of $\mathrm{N}$ and $\mathrm{P}$ although most Ethiopian soils lack other 
macro- and micro-nutrients [3, 4].

Many researchers reported that the use of balanced fertilizers have a promising role in growth and development of crop plants which resulted in improved quality and quantity of the agricultural produce. High fertilizer responsive varieties express their full yield potential when trace elements are applied along with NP fertilizers. Although, nutrient content of the fertilizer that suits the needs and the productivity of the crops, in most part of Ethiopia; particularly Ada'a farmers have limited information on the impact of balanced fertilizer types and rates except only urea and di-ammonium phosphate (DAP) which are source of $\mathrm{N}$ and P. However, new blended fertilizer such as NPSB $\left(18.9 \% \mathrm{~N}, 37.7 \% \mathrm{P}_{2} \mathrm{O}_{5}, 6.95 \% \mathrm{~S}\right.$ and $0.1 \% \mathrm{~B}$ ) is currently being used by the farmers in the study area based on the soil fertility map of the area $[4,5]$.

Growth analysis such as crop growth rate, relative growth rate and leaf area index are the most important traits in prediction of yield. Growth analysis is a suitable method for plant response to different environmental conditions during plant life also observed significant positive interaction between fertilizer treatments and physiological stages of wheat growth [6, 7]. The present study was, therefore, planned to determine the effect of blended NPSB and N fertilizer levels on physiological and growth traits of durum wheat.

\section{Materials and Methods}

A field experiment was conducted at Debre Zeit Agricultural Research Center of Ethiopian Institute of Agricultural Research (EIAR) in 2017 and 2018 cropping season under rain fed condition. Debre Zeit Agricultural Research Center is located in East Shewa Zone of Oromia Regional State. It is found at $47 \mathrm{~km}$ away from South East of the capital city of Ethiopia, Addis Ababa. Its geographical location is $8^{\circ} 44^{\prime} \mathrm{N}$ latitude and $38^{\circ} 58^{\prime} \mathrm{E}$ longitude. The altitude is about 1900 meter above sea level while, the majority of trial fields are heavy soils (Vertisol) with few pockets of light soils (Alfisols/Mollisols) [8]. Mean maximum and minimum temperatures recorded at the station during the season are presented in Figure 1.

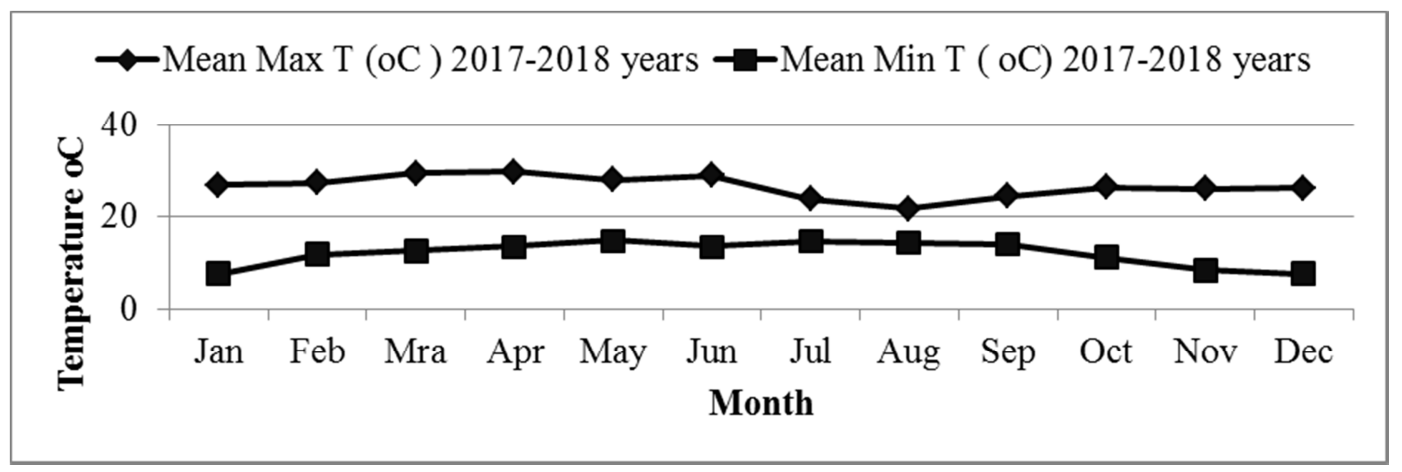

Figure 1. Maximum and minimum monthly temperature 2017-2018 cropping years.

Rainfall data recorded at Deber Zeit Agricultural Research Center weather station indicated moderate monthly rainfall in the area across the years and in season distribution of the cropping season. Ten years (2007 to 2016) and experimental (2017 and 2018) years average monthly rainfall of the experimental site is presented in (Figure 2). The area received an annual rainfall of $824.6 \mathrm{~mm}$ during the cropping season (January to December 2017 to 2018) which was higher than the mean annual rainfall $(788.5 \mathrm{~mm})$ of the ten years.

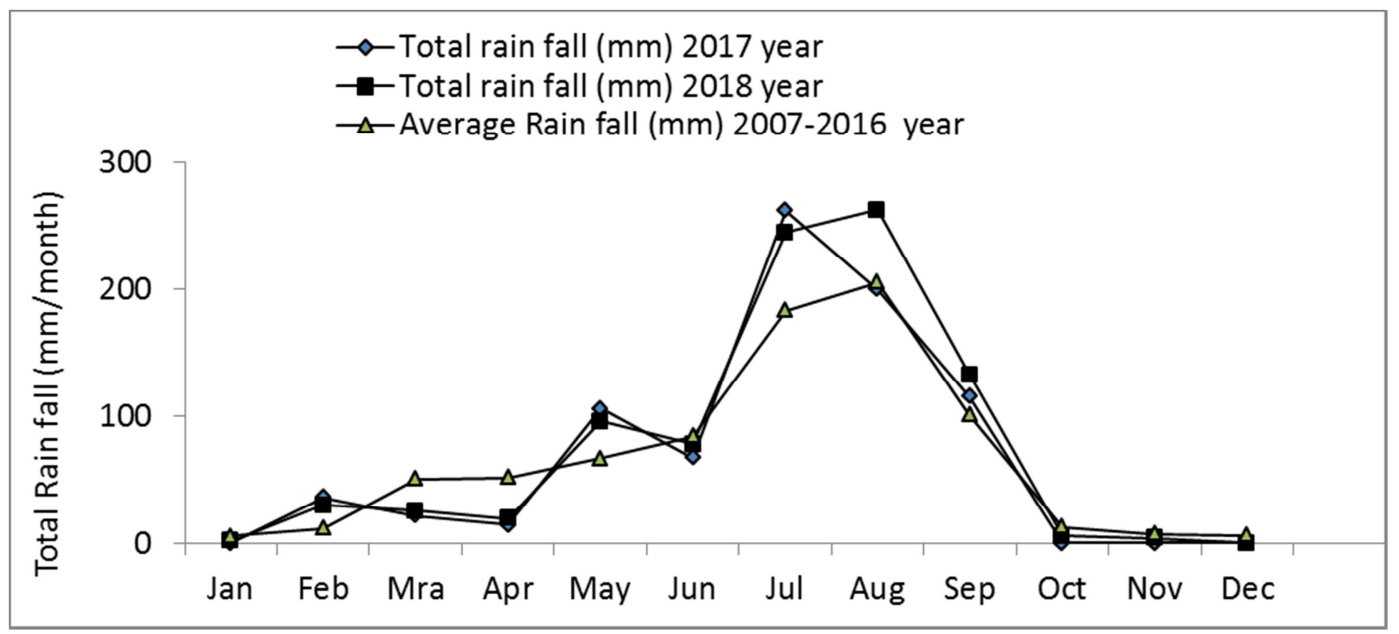

Figure 2. Total rain fall in 2017, 2018 and 2007 to 2016 average monthly rain fall at DZARC. 
Table 1. Selected physical and chemical properties of the experimental soils before sowing in 2017 and 2018 years.

\begin{tabular}{|c|c|c|c|c|c|c|c|c|c|c|}
\hline Year & Clay (\%) & $\begin{array}{l}\text { Silt } \\
(\%)\end{array}$ & $\begin{array}{l}\text { Sand } \\
(\%)\end{array}$ & pH & $\begin{array}{l}\text { CEC } \\
{\left[\mathrm{Cmol}(+) \mathrm{kg}^{-1} \text { soil] }\right.}\end{array}$ & OM & T. N\% & $\begin{array}{l}\text { Av. P } \\
(\mathrm{mg} / \mathrm{kg})\end{array}$ & $\begin{array}{l}\text { Av. S } \\
(\mathrm{mg} / \mathrm{kg})\end{array}$ & $\begin{array}{l}\text { Av. B } \\
(\mathrm{mg} / \mathrm{kg})\end{array}$ \\
\hline 2017 & 54.4 & 30.4 & 15.2 & 6.78 & 50 & 0.71 & 0.092 & 13.23 & 13.01 & 0.402 \\
\hline 2018 & 55.5 & 30.0 & 14.5 & 6.88 & 51 & 0.72 & 0.093 & 13.71 & 13.21 & 0.39 \\
\hline
\end{tabular}

\subsection{Treatments, Design and Field Management}

The treatments consisted of 4 levels of blended $(0,50,100$, and $\left.150 \mathrm{~kg} \mathrm{NPSB} \mathrm{ha}^{-1}\right)$ and 4 levels of $\mathrm{N}(0,46,69$ and $92 \mathrm{~kg}$ $\mathrm{N} \mathrm{ha}^{-1}$ ), fertilizers. A total of 16 treatment combinations were considered. The experiment was laid out in a randomized complete block design (RCBD) in a factorial arrangement replicated 3 times per treatments. The total number of plots in the experiment were $48(16 \times 3)$, each of $3.2 \mathrm{~m} \mathrm{X} 3 \mathrm{~m}(9.6$ $\mathrm{m}^{2}$ ) size. The distances between the plot and block were 0.5 $\mathrm{m}$ and $1.0 \mathrm{~m}$, respectively. Each plot consisted of 16 rows and spaced $20 \mathrm{~cm}$ apart. The net central unit areas of each plot consisting of 8 central rows of $2.80 \mathrm{~m}$ long were harvested and used for growth determination, whereas the others 6 rows were used for destructive measurements. The 2 outer most rows were kept as border plants. For $\mathrm{N}$ fertilizer urea $(46 \% \mathrm{~N})$ and for blended NPSB $\left(18.9 \% \mathrm{~N},-37.7 \mathrm{P}_{2} \mathrm{O}_{5 \%}\right.$, - $6.95 \mathrm{~S} \%,-0.1 \% \mathrm{~B})$ were used as fertilizer source. The experimental field was plowed 2 times by tractor and following breaking clods and leveling the land was done manually. Finally the unit plots were prepared with spade for sowing. The seed of variety Utuba was collected from DZARC and sown with hand drilling on Jul $17^{\text {th }}$ and July $15^{\text {th }}, 2017$ and 2018 respectively, cropping season at the rate of $150\left(\mathrm{~kg} \mathrm{ha}^{-1}\right)$ in $20 \mathrm{~cm}$ rows space in previously tef [Eragrostis tef (Zucc.) Trotter] planted field. The entire blended NPSB fertilizer was applied as per the treatments at a full dose at sowing, whereas $\mathrm{N}$ was applied in two splits ( $1 / 3$ at sowing and $2 / 3$ at tillering about 30 days after sowing) through application of urea. All broad leaf and grass weeds were removed by hand weeding. Additionally, weeding of late-emerging weeds was done to avoid competition with the crop plants for applied N.

\subsection{Data Collection}

Data on the following physiological parameters were recorded as per procedures given below: Total leaf area was measured at 34, 64 and 94 days after sowing destructively using a portable leaf area meter (model CI-202, USA) from $0.1 \mathrm{~m}^{2}$ sampled areas. All green leaves were separated (excluding leaf sheaths) from the plant then the leaf area was measured by leaf area meter. Then after, leaf area index was calculated by using the formula [9].

$$
\text { Leaf area index }(\mathrm{LAI})=\frac{\text { Total leaf area }}{\text { Ground area }}
$$

The calculation of crop growth rate (CGR) and relative growth rate (RGR) require determination of the total dry matter, leaf dry matter and leaf area and the growing degree day (when expressed in terms of thermal time). The procedures followed for the determination of these variables are explained below.

The total dry weight of plant and leaf dry weight were determined based on $0.2 \mathrm{~m} \times 0.5 \mathrm{~m}\left(0.1 \mathrm{~m}^{2}\right)$ samples harvested from each plot at 34,64 , and 94 days after sowing and dried in an oven for 48 hours at $80{ }^{\circ} \mathrm{C}$ and their weight was determined using a sensitive balance.

Calculations based on thermal time are appropriate for an experiment as long as it is recognized that environmental conditions are confounded with treatment [10]. The thermal time was used in the analysis and determined using the following equation. Daily thermal time $\left(\mathrm{tT},{ }^{\circ} \mathrm{C} \quad \mathrm{d}\right)$ was calculated as:

$$
\mathrm{tT}=\left(\frac{\operatorname{Tmax}+\operatorname{Tmin}}{2}-\mathrm{Tb}\right)
$$

Where, $\mathrm{T}$ max, is the maximum daily air temperature with an upper limit of $32^{\circ} \mathrm{C}, \mathrm{T}$ min is the minimum daily air temperature with a lower limit of 6 to $11^{\circ} \mathrm{C}$ which the average is $8.5^{\circ} \mathrm{C}$ for wheat at DZARC [11]. The base temperature for wheat growth is $5^{\circ} \mathrm{C}$ [12]. Therefore, the thermal time accumulated (GDD): which was calculated from date of planting to the date of sampling by summing the following value for each day.

$$
\mathrm{GDD}=\sum_{i=1}^{t}\left(\frac{\text { Tmax }+ \text { Tmin }}{2}-\mathrm{Tb}\right)
$$

Crop growth rate (CGR): It depicts the rate of dry matter production per unit area [13]. The dry weight of plant was determined based on $0.1 \mathrm{~m}^{2}$ samples harvested from each plot at 34, 64, and 94 days after sowing and dried in an oven for 48 hours at $80^{\circ} \mathrm{C}$ and their weight was determined using a sensitive balance. Then, after CGR was calculated by using the formula: given by [14].

$$
\operatorname{CGR}\left(\mathrm{g} \mathrm{m}^{-2}{ }^{\circ} \mathrm{C}_{\text {days }^{-1}}\right)=\frac{W_{2}-W_{1}}{T_{2}-T_{1}} x \frac{1}{G A}
$$

Where $W_{1}$ and $W_{2}$ are dry weight at $T 1$ and $T 2$, respectively, $T_{2}$ and $T_{1}$ are thermal time interval and GA is ground area from which plants were sampled to get dry weight.

Relative growth rate (RGR): Relative growth rate is defined as the rate of dry matter accumulation per unit of existing dry matter [13]. It was calculated as described by as follows [15]:

$$
\operatorname{RGR}\left(\mathrm{g} \mathrm{g}^{-1}{ }^{\circ} \mathrm{C}_{\text {days }^{-1}}\right)=\frac{\ln \left(W_{2}\right)-\ln \left(W_{1}\right)}{T_{2}-T_{1}}
$$

Where $W_{1}$ and $W_{2}$ are dry weight at $T 1$ and $T 2$, respectively, $T_{2}$ and $T_{1}$ are thermal time interval and $\ln$ is the natural logarithm.

Days to $50 \%$ heading: Days to heading was recorded when about $50 \%$ of the plants in a plot produced spikes. 
Days to $90 \%$ physiological maturity: Days to physiological maturity was recorded when about $90 \%$ of the plants reached physiological maturity based on visual observation. It was indicated by senescence (turning to light yellow) of the leaves and vegetative parts as well as free threshing of grain from the glumes when pressed between the forefinger and thumb.

Plant height: At maturity, ten effective tiller plants were taken randomly from the net plot area of each plot and height was measured from the ground to the tip of tillers using ruler and the mean value were determined in $\mathrm{cm}$.

Chlorophyll content at flag leaf stage: The chlorophyll content was measured by SPAD chlorophyll meter Model (CCM-200). The readings of chlorophyll content at flag leaf stage of green leaves were noted from five randomly selected plants and then averaged to get the SPAD chlorophyll content.

\subsection{Data Analysis}

The data subjected to combined analysis of variance (ANOVA) over years after confirmation of homogeneity of error variance using R-software were program. Means of significant treatment effects were separated using Least Significant Difference (LSD) test at 5\% level of significance.

\section{Results and Discussion}

\subsection{Leaf Area Index}

The ANOVA result showed that both the main effects of blended NPSB and N fertilizer rates were highly significantly $(\mathrm{P}<0.01)$ on the leaf area index (LAI) at 64 days after sowing (DAS). The interaction effect of the two factors was also significant $(\mathrm{P}<0.05)$ in influencing the LAI positively at this growth stage (Table 2). However, the main effects of blended NPSB and N fertilizers application were nonsignificant on LAI at 34 and 94 DAS. The interaction effect of these two fertilizers were also non-significant on LAI at both (34 and 94 DAS) growth stage (Table 3).

The highest LAI (4.58) was recorded at the highest rates of $150 / 92 \mathrm{~kg}$ blended NPSB/ $\mathrm{N} \mathrm{ha}^{-1}$, but this was statistically not significantly different from the rates of $100 / 92,150 / 69$, $100 / 69$ and $50 / 92 \mathrm{~kg}$ blended NPSB/N fertilizers $\mathrm{ha}^{-1}$. The lowest LAI (2.46) was obtained from durum wheat grew on the unfertilized plot (Table 2). The application of 150/92 kg blended NPSB $/ \mathrm{N}$ ha ${ }^{-1}$ fertilizers resulted in $86.2 \%$, increase of LAI than the control plot. This might be due to the positive effect of blended NPSB and N fertilizer application in increasing the number and size of wheat leaves on each tiller. The current result is in agreement with the earlier result, significant variation in LAI due to application of different levels of NPK fertilizers at 60 DAS of wheat. Significantly higher (4.8) and lower (3.0) mean LAI of barley from 50:50\% NPS: FYM application and non-fertilized, respectively at 60 DAS $[16,17]$. The results of this experiment indicated that, the use of blended NPSB with the supply of $\mathrm{N}$ fertilizers had positive influence on the LAI particularly at mid growth stages. In general, the combined application of blended NPSB and N at highest rates boosted up the tissue formation with better plant growth which increases its concentration in leaves and results in higher LAI.

Thirty four days after sowing, LAI remained similar in response to the applied fertilizers, which indicated that the nutrient uptake capacity of the durum wheat was very low because of small growth of roots at the initial stage. On the other hand, the lack of significant effect on LAI at 94 DAS might be due to leaf senescence due to plant age (Table 3).

\subsection{Crop Growth Rate}

Crop growth rate (CGR) is regarded as the most meaningful growth function since it represents the net results of photosynthesis, respiration and canopy area interaction [18]. The data pertaining to CGR highly significantly ( $\mathrm{P}<$ 0.01 ) influenced by the main effects of $\mathrm{N}$ rates at 34 to 64 and 64 to 94 days after sowing (DAS). The interaction effect of the two factors also significant $(\mathrm{P}<0.05)$ influenced at both (34 to 64 and 64 to 94 ) times. However, main effect of blended NPSB was no significant effect.

The combined application at a rate of $100 \mathrm{~kg}$ blended NPSB and $92 \mathrm{~kg} \mathrm{~N}^{-1}$ resulted in significantly higher CGR (4.46 $\mathrm{g} \mathrm{m}^{-2 \circ} \mathrm{Cd}^{-1}$ ) as compared to unfertilized plot but remained at par with rates of $150 / 92,150 / 69 \mathrm{~kg} \mathrm{ha}^{-1}$, and 100/69 blended NPSB/N with a CGR of 4.37, 3.60 and 3.47 $\mathrm{g} \mathrm{m}^{-2 \circ} \mathrm{Cd}^{-1}$, respectively at 34 to 64 DAS. The lowest CGR $\left(1.85 \mathrm{~g} \mathrm{~m}^{-2 \circ} \mathrm{Cd}^{-1}\right)$ was recorded at unfertilized plot at 34 to 64 DAS (Table 2). At 64 to 94 DAS, the highest CGR (14.81 $\left.\mathrm{g} \mathrm{m}^{-2 \circ} \mathrm{Cd}^{-1}\right)$ was recorded from the combined application of blended $150 \mathrm{~kg}$ NPSB and $92 \mathrm{~kg} \mathrm{~N}^{-1}$ and this result was found significantly higher than the control treatment $\left(4.67 \mathrm{~g} \mathrm{~m}^{-2}{ }^{\circ} \mathrm{Cd}^{-1}\right)$ but statistically at par with rates of 100/92 and 150/69 $\mathrm{kg}$ blended NPSB/N ha ${ }^{-1}$ which produced a CGR of 13.26, and $10.25 \mathrm{~g} \mathrm{~m}^{-2 \circ} \mathrm{Cd}^{-1}$, respectively (Table 2).

Generally, high CGR values were recorded from the combined application of the two fertilizers at high rates $\left(100 / 92 \mathrm{~kg} \mathrm{NPSB} / \mathrm{N} \mathrm{ha}^{-1}\right)$ at rate one level below the highest ones at 34-64 DAS and the highest rates (150/92 kg NPSB/N $\mathrm{ha}^{-1}$ ) at 64-94 DAS as compared to either the control, or the combined application of the two fertilizers at low rates or the sole application of NPSB or N at all rates. The rapid crop growth rate at the highest rates of blended NPSB and nitrogen might be due to the fact that the plants sufficient absorbed nutrients which might have resulted in higher leaf area which in turn caused higher photosynthesis and dry matter accumulation ultimately resulting in high crop growth rate. This present result agrees with the previous reported, application of $100 \mathrm{~kg} \mathrm{~N}+75 \mathrm{~kg} \mathrm{P}_{2} \mathrm{O}_{5}+50 \mathrm{~kg} \mathrm{~K}_{2} \mathrm{O} \mathrm{ha}^{-1}$ resulted significantly higher crop growth rate $\left(0.227 \mathrm{~g} \mathrm{dm}^{-2}\right.$ days $^{-1}$ ) during 61 to 90 DAS of durum wheat $[5,19]$.

reported that application of boron at $2 \mathrm{~kg} \mathrm{ha}^{-1}$ accelerated crop growth rate of bread wheat $\left(33.40 \mathrm{~g} \mathrm{~m}^{-2}\right.$ days $\left.^{-1}\right)$ as compared to the treatment that received no boron fertilizer (16.67 $\mathrm{g} \mathrm{m}^{-2}$ days ${ }^{-1}$ ) at 49 to 98 DAS. 
Table 2. Interaction effect of blended NPSB and N fertilizers on leaf area index at 64, CGR at 34-64 and 64-94 and RGR at 34-64 DAS of durum wheat.

\begin{tabular}{|c|c|c|c|c|c|}
\hline \multirow{2}{*}{ Blended NPSB $\left(\mathrm{kg} \mathrm{ha}^{-1}\right)$} & \multirow{2}{*}{ Nitrogen $\left(\mathrm{kg} \mathrm{ha}^{-1}\right)$} & \multirow{2}{*}{ 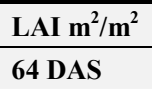 } & \multicolumn{2}{|c|}{ CGR $\left(\mathrm{g} \mathrm{m}^{-2}{ }^{\circ} \mathrm{Cdays}^{-1}\right)$} & \multirow{2}{*}{$\begin{array}{l}\text { RGR }\left(\mathrm{g} \mathrm{g}^{-1}{ }^{0} \mathrm{Cdays}^{-1}\right) \\
\text { 34-64 DAS }\end{array}$} \\
\hline & & & 34-64 DAS & 64-94 DAS & \\
\hline \multirow[t]{4}{*}{0} & 0 & $2.46 \mathrm{~g}$ & $1.85 \mathrm{e}$ & $4.67 \mathrm{~d}$ & $0.0049 \mathrm{e}$ \\
\hline & 46 & $2.48 \mathrm{~g}$ & $2.12 \mathrm{de}$ & $5.66 \mathrm{~cd}$ & $0.0051 \mathrm{de}$ \\
\hline & 69 & $2.77 \mathrm{~d}-\mathrm{g}$ & $2.48 \mathrm{c}-\mathrm{e}$ & $7.86 \mathrm{~cd}$ & $0.0057 \mathrm{~b}-\mathrm{e}$ \\
\hline & 92 & $2.68 \mathrm{fg}$ & $2.58 \mathrm{c}-\mathrm{e}$ & $6.70 \mathrm{~cd}$ & $0.0067 \mathrm{a}-\mathrm{d}$ \\
\hline \multirow[t]{4}{*}{50} & 0 & $2.71 \mathrm{e}-\mathrm{g}$ & $2.62 \mathrm{c}-\mathrm{e}$ & $5.71 \mathrm{~cd}$ & $0.0066 \mathrm{a}-\mathrm{d}$ \\
\hline & 46 & $3.03 \mathrm{c}-\mathrm{g}$ & $2.91 \mathrm{c}-\mathrm{e}$ & $8.30 \mathrm{~cd}$ & $0.0056 \mathrm{c}-\mathrm{e}$ \\
\hline & 69 & $3.44 \mathrm{~b}-\mathrm{f}$ & $3.25 \mathrm{bc}$ & $9.36 \mathrm{~b}-\mathrm{d}$ & $0.0063 \mathrm{a}-\mathrm{e}$ \\
\hline & 92 & $3.87 \mathrm{a}-\mathrm{c}$ & $2.96 \mathrm{c}-\mathrm{e}$ & $9.61 \mathrm{bc}$ & $0.0058 \mathrm{~b}-\mathrm{e}$ \\
\hline \multirow[t]{4}{*}{100} & 0 & $3.09 \mathrm{c}-\mathrm{g}$ & $2.83 \mathrm{c}-\mathrm{e}$ & $5.97 \mathrm{~cd}$ & $0.0061 \mathrm{a}-\mathrm{e}$ \\
\hline & 46 & $3.64 \mathrm{~b}-\mathrm{d}$ & $3.01 \mathrm{~cd}$ & $9.54 b c$ & $0.0063 \mathrm{a}-\mathrm{e}$ \\
\hline & 69 & $3.90 \mathrm{a}-\mathrm{c}$ & $3.47 \mathrm{a}-\mathrm{c}$ & $9.98 \mathrm{bc}$ & $0.0072 \mathrm{ab}$ \\
\hline & 92 & $4.28 \mathrm{ab}$ & $4.46 \mathrm{a}$ & $13.26 \mathrm{ab}$ & $0.0071 \mathrm{a}-\mathrm{c}$ \\
\hline \multirow[t]{4}{*}{150} & 0 & $2.82 \mathrm{~d}-\mathrm{g}$ & $2.77 \mathrm{c}-\mathrm{e}$ & $6.44 \mathrm{~cd}$ & $0.0052 \mathrm{de}$ \\
\hline & 46 & $3.60 \mathrm{~b}-\mathrm{e}$ & $3.23 \mathrm{~cd}$ & $9.71 \mathrm{bc}$ & $0.0065 \mathrm{a}-\mathrm{d}$ \\
\hline & 69 & $4.03 \mathrm{ab}$ & $3.60 \mathrm{a}-\mathrm{c}$ & $10.25 \mathrm{a}-\mathrm{c}$ & $0.0062 \mathrm{a}-\mathrm{e}$ \\
\hline & 92 & $4.58 \mathrm{a}$ & $4.37 \mathrm{ab}$ & $14.81 \mathrm{a}$ & $0.0077 \mathrm{a}$ \\
\hline $\operatorname{LSD}(5 \%)$ & & 0.90 & 1.13 & 4.78 & 0.0016 \\
\hline CV (\%) & & 8.85 & 12.23 & 18.25 & 8.67 \\
\hline
\end{tabular}

$\mathrm{LAI}=\mathrm{Leaf}$ area index; $\mathrm{CGR}=$ Crop growth rate; $\mathrm{RGR}=$ Relative growth rate; $\mathrm{DAS}=$ days after sowing; Means with the same letter in columns are not significantly different at $5 \%$ level of significance; $\mathrm{LSD}=$ least significant differences at $5 \% ; \mathrm{CV}(\%)=$ Coefficient of variation. $c-g=c d e f g, b-d=b c d, e-g=e f g$.

\section{Relative growth rate}

Relative growth rate (RGR) expresses the dry weight increase in time interval in relation to the initial weight. The analysis of variance showed that the main effects of blended NPSB and N as well as their interaction highly significantly $(\mathrm{P}<0.01)$ affected the RGR at 34 to 64 days after sowing (Table 2). However, the main effects of the blended NPSB and $\mathrm{N}$ fertilizers as well as their interaction effect on RGR at 64 to 94 days after sowing were found to be not significant (Table 3).

The 2 fertilizers interacted significantly to influence the RGR of durum wheat at 34 to 64 days after sowing (Table 2). The highest RGR $(0.0077 \mathrm{~g} \mathrm{~g}-1 \mathrm{oCd}-1)$ was found at the combined application of highest rate of blended NPSB and N
(150/92 kg NPSB/N ha-1) fertilizers, which was statistically at par with the rates of $100 / 69$ and 100/92 $\mathrm{kg}$ blended NPSB/N ha-1 fertilizers application (Table 2). The lowest RGR (0.0049 g g-1 oCd-1) was obtained at untreated plot. This indicated that the RGR was more enhanced by both blended NPSB and N fertilizers, which might be due to the high concentrations of nutrients in fairly fertilized plots causing production of more leaves which in turn contributes for the production of high dry matter which resulted in more RGR [5]. In contrast to this result, previously reported indicated that the nutrient management could not influence RGR significantly at 30 to 60 DAS but significantly higher RGR was reached at 60 to 90 DAS of bread wheat [16].

Table 3. Main effects of blended NPSB and N fertilizers on LAI at 34, 94 and RGR at 64-94 DAS of durum wheat.

\begin{tabular}{|c|c|c|c|}
\hline \multirow{2}{*}{ Blended NPSB $\left(\mathrm{kg} \mathrm{ha}^{-1}\right)$} & \multicolumn{2}{|c|}{$\operatorname{LAI}\left(\mathrm{m}^{2} / \mathrm{m}^{2}\right)$} & \multirow{2}{*}{$\begin{array}{l}\text { RGR }\left(\mathrm{g} \mathrm{g}^{-1}{ }^{0} \mathrm{Cdays}^{-1}\right) \\
64 \text { to } 94 \text { DAS }\end{array}$} \\
\hline & 34 DAS & 94 DAS & \\
\hline 0 & 1.97 & 1.60 & 0.00464 \\
\hline 50 & 1.89 & 1.59 & 0.00470 \\
\hline 100 & 1.94 & 1.49 & 0.00477 \\
\hline 150 & 2.10 & 1.39 & 0.00464 \\
\hline $\operatorname{LSD}(5 \%)$ & NS & NS & NS \\
\hline \multicolumn{4}{|l|}{ Nitrogen $\left(\mathrm{kg} \mathrm{ha}^{-1}\right)$} \\
\hline 0 & 1.92 & 1.42 & 0.00459 \\
\hline 46 & 1.89 & 1.62 & 0.00464 \\
\hline 69 & 2.05 & 1.56 & 0.00470 \\
\hline 92 & 2.05 & 1.48 & 0.00482 \\
\hline $\operatorname{LSD}(5 \%)$ & NS & NS & 0.00401 \\
\hline CV (\%) & 12.64 & 16.75 & NS \\
\hline
\end{tabular}

$\mathrm{LAI}=$ Leaf area index; RGR= Relative growth rate; DAS= days after sowing; Means with the same letter in columns are not significantly different at $5 \%$ level of significance; $\mathrm{LSD}=$ least significant differences at $5 \%$; CV $(\%)=$ Coefficient of variation. 


\subsection{Plant Height}

The analysis of variance revealed that the main effect of nitrogen fertilizer rates highly significantly $(\mathrm{P}<0.01)$ influenced the plant height. However, the main effect of blended NPSB as well as the interaction effect did not significantly influence this parameter.

The tallest plant $(89.43 \mathrm{~cm})$ was obtained at the highest rate of $\mathrm{N}$ application $\left(92 \mathrm{~kg} \mathrm{ha}^{-1}\right)$ and it was at par with plant height recorded in plants from nitrogen application at rates of $69(89.06 \mathrm{~cm})$ and $46(86.69 \mathrm{~cm}) \mathrm{kg} \mathrm{N} \mathrm{ha}{ }^{-1}$. The shortest plant height $(86.51 \mathrm{~cm})$ was recorded in unfertilized plot (Table 4). The application of nitrogen fertilizer at 92 and 69 $\mathrm{kg} \mathrm{N} \mathrm{ha}{ }^{-1}$ increased the plant height by $3.7 \%$, and $2.95 \%$, respectively, compared to the unfertilized plot. This increment in plant height might be due to the fact that $\mathrm{N}$ improves plant height by taking synthesis of macromolecules (proteins, enzymes, pigments, hormones, etc.) and rate of processes like photosynthesis on cell division and cell elongation, and finally internode length. Soil applied with increased rates of $\mathrm{N}$, increase internodes length which ultimately resulted in increased plant height also $\mathrm{N}$ application enhanced the overall vegetative growth of bread wheat [20]. In conformity with this result, nitrogen fertilizer rate increased from nil to $69 \mathrm{~kg} \mathrm{ha}^{-1}$, the plant height of bread wheat increased from $82.63 \mathrm{~cm}$ to $94.18 \mathrm{~cm}$ [21].

\subsection{Chlorophyll Content at Flag Leaf Stage}

The analysis of variance showed that chlorophyll content increased to be significantly $(\mathrm{P}<0.05)$ affected by only the main effect of nitrogen fertilizer rates. However, the main effect of blended NPSB as well as the interaction of the two factors was not significant.

The highest chlorophyll content mean SPAD values of $40.09 \% 38.15 \%$ were obtained in the application of 92 and $69 \mathrm{~kg} \mathrm{~N} \mathrm{ha}^{-1}$, respectively, while the lowest mean chlorophyll content $(37.70 \%)$ was recorded in untreated plot (Table 4). Increasing the rate of nitrogen fertilizer from nil to $69 \mathrm{~kg} \mathrm{~N}$ $\mathrm{ha}^{-1}$ increased the chlorophyll content by about $3.5 \%$. Increasing the rate of nitrogen further from 69 to $92 \mathrm{~kg} \mathrm{~N} \mathrm{ha}^{-1}$ increased the chlorophyll content by about $5.1 \%$ although the change was non-significant (Table 4). This showed that supply of $\mathrm{N}$ at rate of $69 \mathrm{~kg} \mathrm{ha}^{-1}$ is found to be adequate for enhancing this parameter. The result of the present study showed that nitrogen was more effectual on the chlorophyll content than other plant nutrients. The possible reason might be due to the fact that $\mathrm{N}$ is one of the constituent element of chlorophyll and a major component of all enzymes and hence it plays important role in chlorophyll formation, photosynthesis, chloroplast development and respiration of plants and other biochemical and physiological activates [22]. Corroborating the result of this study, significant increments in chlorophyll content at flag leaf stage in response to increasing the rate of nitrogen application, in which case they found that the highest numbers 38.31 and $35.4 \mathrm{SPAD}$ in $\%$ were recorded for treatments that received
210 and $200 \mathrm{~kg} \mathrm{~N} \mathrm{ha}^{-1}$, respectively $[23,24]$.

\subsection{Days to Heading}

The main effect of $\mathrm{N}$ fertilizer rates highly significantly $(\mathrm{P}<0.01)$ influenced days to heading. However, the main effects of blended NPSB as well as the interaction effect of the two factors were not significant.

The delayed days to heading (562.65 degree days) was recorded in $92 \mathrm{~kg} \mathrm{~N} \mathrm{ha}^{-1}$ which was statistically at par with the rate of $69 \mathrm{~kg} \mathrm{~N} \mathrm{ha}{ }^{-1}$, while the earliest days to heading (535.8 degree days) was recorded in the control (unfertilized) plot (Table 4). As indicated in Table 4, increasing $\mathrm{N}$ fertilizer from nil to $69 \mathrm{~kg} \mathrm{~N}$ ha $^{-1}$ delayed days' to heading by $2.9 \%$. Increasing the rate of $\mathrm{N}$ from nil to $92 \mathrm{~kg} \mathrm{~N} \mathrm{ha}^{-1}$ further prolonged the days to heading by $4.9 \%$. This might be due to the fact that $\mathrm{N}$ has promoted greater vegetative development for longer period of time before reproductive phase begins and hence might have caused delay in heading. This result is consistent, indicated that wheat plants grew under increased rates of nitrogen fertilizer supply delayed days to headings than those grew low rates of the nutrient. Moreover, the $\mathrm{N}$ level increased from nil to $69 \mathrm{~kg} \mathrm{ha}^{-1}$, the days to $50 \%$ heading was delayed from 67.58 to 70.04 days of bread wheat $[21,25]$. The result of present study is contrary; found that $\mathrm{N}$ at the rate of $64 \mathrm{~kg} \mathrm{ha}^{-1}$ significantly reduced days to heading of tef over the control [26].

Lack of increasing trend between blended NPSB and interaction effects of blended NPSB and N fertilizer rates could be attributed to the counteracting effects of $\mathrm{P}$ nutrient on $\mathrm{N}$ nutrient effects because $\mathrm{N}$ tends to increase vegetative growth, while $\mathrm{P}$ hastens the reproductive growth. Previously finding also showed that under no $\mathrm{P}$ application, days to heading showed an increasing tendency with rising $\mathrm{N}$ rates on barley (Hordeum vulgare L.)[27].

\subsection{Days to Physiological Maturity}

Days to physiological maturity was highly significantly ( $\mathrm{P}$ $<0.01)$ influenced by the main effect of nitrogen fertilizer rates. However, neither the main effect of blended NPSB nor the interaction effect of blended NPSB and N application significantly influenced this parameter.

Similar to number of days to heading, application of high rate of $\mathrm{N}$ delayed days to physiological maturity of durum wheat (Table 4). Delay in maturity time of this crop was greater at highest rate of nitrogen than at nil rates. The 2 top $\mathrm{N}$ rates $\left(92\right.$ and $69 \mathrm{~kg} \mathrm{ha}^{-1}$ ) were at par among each other and they were significantly different from the other 2 lower rates of $\mathrm{N}$ treatments. About 3 more days were required for the 92 $\mathrm{kg} \mathrm{N} \mathrm{ha}^{-1}$ treatment when compared to the control which took (1060.6 degree days) to physiological maturity (Table 4). Generally, number of days to maturity was delayed by about $2.34 \%$ by the application of $92 \mathrm{~kg} \mathrm{~N} \mathrm{ha}^{-1}$ as compared to that of unfertilized plot. This may be attributed to the physiological effect of the fertilizer $\mathrm{N}$ which increases vegetative growth of crops where by it delays maturity time. 
The fact that $\mathrm{N}$ is important for synthesis of major macromolecules in plants including proteins, enzymes, pigments, growth promoting hormones, etc. which are important for maintaining and producing vegetative tissues and cell organelles which in turn contribute for the delay of maturity of plants. In line with this result, the highest doses of N (69 $\mathrm{kg} \mathrm{ha}^{-1}$ ) delayed physiological maturity of bread wheat by about three days (from 123.87 to 127.00 days) as compared to the control [21]. In contrary to the current finding, shortest days (91) to physiological maturity of tef were obtained from the application of $69 \mathrm{~kg} \mathrm{~N} \mathrm{ha}^{-1}$ and $30 \mathrm{~kg} \mathrm{P}_{2} \mathrm{O}_{5} \mathrm{ha}^{-1}$ and the longest days (97) from the control [28].

Table 4. Main effects of blended NPSB and N fertilizers on plant height, Chlorophyll content days to heading and days to physiological maturity of durum wheat.

\begin{tabular}{|c|c|c|c|c|}
\hline Treatments & PH (cm) & ChL (SPADValue in\%) & DH in DD & DPM in DD \\
\hline \multicolumn{5}{|c|}{ Blended NPSB $\left(\mathrm{kg} \mathrm{ha}^{-1}\right)$} \\
\hline 0 & 87.26 & 36.51 & 551.24 & 1048.1 \\
\hline 50 & 87.71 & 38.55 & 547.80 & 1045.9 \\
\hline 100 & 88.03 & 38.66 & 554.69 & 1056.1 \\
\hline 150 & 88.68 & 39.07 & 552.59 & 1051.8 \\
\hline $\operatorname{LSD}(5 \%)$ & NS & NS & NS & NS \\
\hline \multicolumn{5}{|c|}{ Nitrogen $\left(\mathrm{kg} \mathrm{ha}^{-1}\right)$} \\
\hline 0 & $86.51 b$ & $36.86 b$ & $535.82 \mathrm{c}$ & $1036.2 b$ \\
\hline 46 & $86.69 \mathrm{ab}$ & $37.70 \mathrm{ab}$ & $540.65 b c$ & $1037.0 \mathrm{~b}$ \\
\hline 69 & $89.06 \mathrm{ab}$ & $38.15 \mathrm{ab}$ & $551.07 \mathrm{ab}$ & $1058.8 \mathrm{a}$ \\
\hline 92 & $89.43 a$ & $40.09 a$ & $562.65 \mathrm{a}$ & $1060.6 \mathrm{a}$ \\
\hline LSD (5\%) & 2.88 & 2.81 & 10.04 & 9.2 \\
\hline CV $(\%)$ & 2.95 & 6.62 & 2.20 & 1.06 \\
\hline
\end{tabular}

$\mathrm{PH}=$ plant height $\mathrm{CHL}=$ chlorophyll content $=\mathrm{DH}=$ days to heading in degree days; $\mathrm{DM}$ days to physiological maturity in degree days; Means with the same letter in columns are not significantly different at 5\% level of significance; LSD= least significant differences at 5\%; CV (\%) $=\mathrm{Coefficient}$ of variation.

\section{Conclusion}

As the results of this study indicated that application of blended NPSB with the supplement $\mathrm{N}$ fertilizers have positive effects on physiological growth indices of durum wheat. The investigation showed that the maximum leaf area index, crop growth rate, and relative growth rate were obtained at the highest rates of combined application of blended NPSB and N fertilization. On the other hand, chlorophyll content, days to heading, days to physiological maturity and plant height was recorded at the highest levels nitrogen fertilizer. However, definite recommendation may not be drawn from this research result, as the present result came from one location and cultivar. Therefore, it is advisable to undertake further research across season and locations involving yield and yield component traits and more than one cultivar to draw sound recommendation.

\section{References}

[1] Bonjean AP, Angus WJ and Ginkel M. (2016) The world wheat book: A history of wheat breeding Vol. 3. Lavoisier, Paris.

[2] CSA (Central Statistical Agency), (2017) Agricultural Sample Survey 2016/2017 Agricultural Sample Survey. Agricultural sample survey, report on area and production of major crops, Addis Ababa, Ethiopia.

[3] Kidane G. (2015) Dryland Agriculture Production Systems in Ethiopia. National Publishers, Addis Ababa, Ethiopia.

[4] EthioSIS (Ethiopian Soil Information System), (2014). Soil analysis report Agriculture Transformation Agency (Unpublished).
[5] Nataraja TH, Halepyati A S, Pujari B T and Desai B K. (2006) Influence of phosphorus levels and micronutrients on physiological parameters of wheat (Triticum durum Desf.). Karnataka Journal Agricultural Science, 19 (3): 685-687.

[6] Tesar M B. (1984) Physiological basis of crop growth and development. American Society of Agronomy. Madison. Wisconsin, pp.: 291-321.

[7] Mandal A, Patra AK, Singh D, Swarup A and Masto RE. (2007) Effect of long-term application of manure and fertilizer on biological and biochemical activities in soil during crop development stages. Bioresource Technology, 98: 3585-3592.

[8] WRB (World Reference Base). (2006) A framework for international classification, correlation and communication, world soil resource report 103, Rome, p68.

[9] Diwaker B and Oswalt D L. (1992) Research planning and data handling. ICRISAT. Andhra Pradesh, India. 89 p.

[10] Russelle M. P, Wilhelm WW, Olsen R A and Power J F. (1984) Growth analysis based on degree days. Crop Science, 24: 28-32.

[11] Cao W and Moss DN. (1989) Temperature effect on leaf emergence and phyllochron in wheat and barley. Crop Science, 29: 1018-1021.

[12] White JW, Tanner D G and Corbett J D. (2001) An AgroClimatological Characterization of Bread Wheat Production Areas in Ethiopia. NRG-GIS Series 01-01. Mexico D. F. CIMMYT.

[13] Warren W J. (1981) Analysis of growth, photosynthesis and light interception for single stands. Annual Botany, 31: 41-57.

[14] Brown R H, (1984) Growth of the green plant. In: Tesar M. B. (ed.), Physiological Basis of Crop Growth and Development. American Society of Agronomy, Madison, WI, pp. 153-174. 
[15] Gardner F P, Pearce R B and Mitchell R L. (1985) Physiology of Crop Plants. pp. 186-208.

[16] Prasad S. (2017) Effect of sowing time and nutrient management on growth and yield of heat tolerant varieties of wheat. College of Agriculture, Jawaharlal Nehru Krishi Vishwa Vidyalaya, Jabalpur, Ph. D. Thesis.

[17] Tariku B, Abera T and Ermiyias H. (2018) Effect of integrated nutrient management on growth and yield of food barley (Hordeum vulgare) variety in Toke Kutaye District, West Showa Zone, Ethiopia. Advances in Crop Science and Technology, 6: 3. doi: 10.4172/2329-8863.1000365.

[18] Alam M Z and Haider S A. (2006) Growth attributes of barley (Hordeum vulgare L.) cultivars in relation to different doses of nitrogen fertilizer. Journal of Life and Earth Sciences; 1 (2): $77-82$.

[19] Nadeem M, Qazi JI, Syed Q and Gulsher M. (2013) Purification and characterization of an alkaline protease from Bacillus licheniformis UV-9 for detergent formulations. Songklanakari Journal Science Technology, 35: 187-195.

[20] Saeed B, Gul H, Ali F, Khan A Z, Anwar S, Alam S, Khalid S, Naz A and Fayyaz H. (2013) Contribution of soil and foliar fertilization of nitrogen and sulfur on physiological and quality assessment of wheat (Triticum aestivum L.). Natural Science, 5: 1012-1018.

[21] Melesse H. (2017) Response of bread wheat (Triticum aestivum L.) varieties to $\mathrm{N}$ and $\mathrm{P}$ fertilizer rates in Ofla district, Southern Tigray, Ethiopia. African Journal of Agricultural Research, 12 (19): 1646-1660.
[22] Zeidan M S, Mana F and Hamouda H A. (2010) Effect of foliar fertilization of $\mathrm{Fe}, \mathrm{Mn}$ and $\mathrm{Zn}$ on wheat yield and quality in low sandy soils fertility. World Journal Agricultural Science, 6: 696-699.

[23] Brian, N O, M Mohamed and Joel K R. (2007) Seeding rate and nitrogen management effects on spring wheat yield and yield components. American Journal of Agronomy, 99: 1615-1621.

[24] Ali R, Khan MJ and Khattak RA. (2008) Response of rice to different sources of Sulfur (S) at various levels and its residual effect on wheat in rice-wheat cropping system. Soil Environment, 27 (1): 131-137.

[25] Muhammad Z, Ahmad G, Iqbal B, M Khan R, Bari A and Shah S. (2016) Effect of fertilizer dose on the performance of spring cereals. Pure and Applied Biology, 5 (3): 458-463.

[26] Sate S. (2012) Effects of Inorganic Fertilizer Types and Sowing Methods of Different Seed Rates on Yield and Yield Components of Tef in Boreda District, Southern Ethiopia. M. Sc. Thesis, Haramaya University, Haramaya, Ethiopia.

[27] WakeneT, Walelign $\mathrm{W}$ and Wassie H. (2014) Effects of nitrogen and phosphorus fertilizer levels on growth and development of barley (Hordeum vulgare L.) at Bore District, Southern Oromia, Ethiopia. American Journal of Life Sciences, 2 (5): 260-266.

[28] Getahun D, Dereje A, Tigist A and Bekele A. (2018) Response of yield and yield components of Tef [Eragrostis tef (Zucc.) Trotter] to optimum rates of nitrogen and phosphorus fertilizer rate application in Assosa Zone, Benishangul Gumuz Region. Ethiopian Journal Agricultural Science, 28 (1) 81-94. 